\title{
Distribution of soil nematode communities along a section of Shen-Ha Highway
}

\author{
V. V. S. TOMAR ${ }^{1,2}$, X. K. ZHANG ${ }^{1}$, Q. LI ${ }^{1}$, Y. JIANG ${ }^{1}$, W. J. LIANG ${ }^{1, *}$
}

\author{
${ }^{1}$ Key Laboratory of Terrestrial Ecological Process, Institute of Applied Ecology, Chinese Academy of Sciences, \\ Shenyang 110016, China, *E-mail: liangwj@iae.ac.cn; ${ }^{2}$ Nematode Biodiversity Research Laboratory, Aligarh Muslim \\ University, Aligarh 202002, India
}

\begin{abstract}
Summary
The effect of lead on soil nematode communities at the $0-$ $20 \mathrm{~cm}$ depth was investigated along an increasing distance from a highway in Northeast China. The results showed that the abundance of total nematodes significantly increased from $40 \mathrm{~m}$ and then decreased eventually and the similar trend was also found in most indices studied. Thirty seven genera of nematodes belonging to 8 orders and 24 families were observed in our study, and Helicotylenchus was eudominant genus at all the sampling sites. The numbers of total nematodes significantly correlated with total and available $\mathrm{Pb}(\mathrm{P}<0.05)$, while $\Sigma \mathrm{MI}$ had a significantly negative correlation with TOC, Total N $(\mathrm{P}<0.01)$ and $\mathrm{C} / \mathrm{N}$ ratio $(\mathrm{P}<0.05)$. Total and available $\mathrm{Pb}$ in soil had positive correlation with the numbers of total nematodes and bacterivores. The concentration of $\mathrm{Pb}$ also had an effect on abundance of Helicotylenchus, which increased in moderate concentration of $\mathrm{Pb}$. NCR could be effectively used as indicators, as it was sensitive to concentration of $\mathrm{Pb}$.
\end{abstract}

Keywords: soil nematodes; community structure; ecological indices; highway; lead

\section{Introduction}

The contribution of vehicular exhaust to the global emission of atmospheric pollutants is increasing at alarming rate. The pollutants that mainly include $\mathrm{Pb}, \mathrm{Cd}$ and $\mathrm{Zn}$ have an impact on environment. The exhausts from vehicles contaminate the atmosphere, water and soil due to deposition. Many studies have shown contamination by these elements, at the vicinity of highways (Zhang et al., 1999; Turner \& Maynard, 2003). The concentration of heavy metals in the roadside soils may be influenced by factors like wind (Piron-Frenet et al., 1994) or traffic intensity (Garcia \& Millan, 1998) and by soil physiochemical characteristics. Heavy metals in this exhaust are usually dispersed in relatively higher concentrations in the vicinity of a highway, with a gradual depletion as distance from the source increases (Sezgin et al., 2003; Nabulo et al., 2006). Most vehicles burn leaded gasoline, which is well established source of $\mathrm{Pb}$ contamination to environment. Mielke et al. (1997) observed that accumulation of $\mathrm{Pb}$ in soil due to leaded gasoline is directly proportional to highway traffic flow. Nematodes are important component of soil ecosystems and any changes in the soil characteristics may result in change in community dynamics of the nematodes, which can be assessed with the help of ecological indices. Nematode community structure is widely used as a tool in ecological studies, to assess the functioning of soil and biomonitoring. Nematode fauna composition along with its indices, has emerged as a useful monitor for environmental conditions and soil ecosystem function and also helpful in assessing the effects of various soil disturbances (Bongers \& Ferris, 1999; Neher, 2001; Berkelmans et al., 2003).

In recent years, there are many reports of the impact of heavy metals on soil ecosystems. Sezgin et al. (2003) studied contamination of highway soils with heavy metals in Turkey and reported heavy concentration of lead in the soils near highway. Viard et al. (2004) assessed the bioaccumulation of heavy metals $(\mathrm{Pb}, \mathrm{Cd}, \mathrm{Zn})$ in soil, plants of graminacae and garden snails; and reported that lead efficiently described traffic impact and it was the most adapted tracer of highway environment. Nabulo et al. (2006) assessed the contamination of roadside soils with heavy metals in Uganda and found concentration of heavy metals decreased with increasing distance from roads. Wang et al. (2006) compared the distribution pattern of lead in rural and urban Shenyang city and found that east sides of the road were more contaminated as compared to west sides. Many studies have been performed to evaluate nematode responses to heavy metals from sources like industrial complex (Shukurov et al., 2005), metallurgical factory in China (Li et al., 2006; Zhang et al., 2007), however, there is little information on soil nematode responses to heavy 
metal pollution from a highway. The objective of this study was to investigate the distribution of soil nematodes along a $\mathrm{Pb}$ pollution gradient with increasing distance from a highway in Northeast China.

\section{Material and Methods}

This study was conducted at a maize field that was distributed near a highway. Soil samples were collected from the maize field along the section of Shen-Ha highway between Shenyang and Tieling, which are all the large cities in Liaoning, Northeast China. The section suited in the Puhe town $\left(41^{\circ} 57^{\prime} \mathrm{N}, 123^{\circ} 36^{\prime} \mathrm{E}\right)$ far from the centre of Shenyang city. The section of highway is characterized by a traffic level of 50,000 vehicles and 300,000 passenger flow per day. The study site is located in the continental monsoon zone with a dry-cold winter and a warm-wet summer. The annual temperature is $7.3{ }^{\circ} \mathrm{C}$, mean annual precipitation is $667 \mathrm{~mm}$. The test soil is classified as a Hapli-Udic Argosol in Chinese soil taxonomy (Hua et al., 2006), with $12.75 \mathrm{~g} \mathrm{~kg}^{-1}$ total $\mathrm{C}$, and $1.11 \mathrm{~g} \mathrm{~kg}^{-1}$ total $\mathrm{N}, \mathrm{pH}$ $\left(\mathrm{H}_{2} \mathrm{O}\right) 6.3,38.0 \%$ sand, $41.4 \%$ silt and $20.6 \%$ clay at the $0-20 \mathrm{~cm}$ depth.

Soil samples at the $0-20 \mathrm{~cm}$ depth were taken from the maize field $(100 \mathrm{~m} \times 320 \mathrm{~m})$ along a pollution gradient with distance at 5, 20, 40, 80, 160 and 320 meters in a downwind direction from the east side of highway on October 5, 2007. Five replications were collected by coring techniques $(5 \mathrm{~cm}$ diameter). Each replication was composed of 5 soil cores. Soil samples were placed in individual plastic bags and transported to the laboratory for chemical and nematode analysis.

Before chemical analysis, soil samples were air-dried, ground to pass through a $2 \mathrm{~mm}$ sieve for determination of available $\mathrm{Pb}$. Subsamples were then ground and passed through a $149 \mu \mathrm{m}$ sieve for determination of total $\mathrm{Pb}$. Soil samples were digested with $\mathrm{HF}-\mathrm{HNO}_{3}-\mathrm{HClO}_{4}(3: 1, \mathrm{v} / \mathrm{v})$ and determined using AAS (WFX120A) with detecting limit of $0.01 \mathrm{mg} / \mathrm{L}$ for total $\mathrm{Pb}$. The concentrations of available $\mathrm{Pb}$ in soil samples was determined after extraction with $0.1 \mathrm{~mol} / \mathrm{L} \mathrm{HCL}$ (solid: liquid =1:5) (Li et al., 2006; Qin et al., 2009).

Nematodes were extracted from $100 \mathrm{~g}$ (fresh weight) of soil from each sample using modified Baermann's funnel technique (Tomar et al., 2006). The nematode abundance was expressed per $100 \mathrm{~g}$ dry weight soil (Liang et al., 2007). All extracted nematodes in each sample were counted and identified to genus level using an inverted compound microscope. The classification of trophic groups was assigned to: (1) bacterivores (Ba); (2) fungivores $(\mathrm{Fu})$; (3) root-fungal feeders (RFF); (4) herbivores /plant-parasites (H); (5) omnivores (OM) and (6) carnivores/predators) (Ca), based on known feeding habitats or stoma and esophageal morphology (Yeates et al., 1993; Háněl, 2004; Renčo, 2004; Okada et al., 2005).

Following ecological indices of nematode communities were calculated: (1) Dominance $\lambda=\Sigma \mathrm{pi}^{2}$; (2) ShannonWeaver diversity $\mathrm{H}^{\prime}=-\Sigma$ pi lnpi, where pi is the proportion of individuals in the ith taxon; (3) Species richness $\mathrm{SR}=$ $(\mathrm{S}-1) / \mathrm{lnN}$, where $\mathrm{N}$ is the number of nematodes; (4) Evenness $\left(\mathrm{J}^{\prime}\right)=\mathrm{H}^{\prime} / \mathrm{lnS}, \mathrm{S}$ (nematode taxon richness) is the total number of genera (Yeates \& Bongers, 1999); (5) $\Sigma$ maturity index $\Sigma \mathrm{MI}=\Sigma \mathrm{v}(\mathrm{i}) \cdot \mathrm{f}(\mathrm{i})$, where $\mathrm{v}(\mathrm{i})$ is the c-p value of taxon i, f (i) is the frequency of taxon i in a sample; (6) MI2-5 (excluding c-p 1 group) (Bongers, 1990; Korthals et al., 1996; Yeates et al., 2003; Nagy et al., 2004); (7) Nematode channel ratio (NCR), $\mathrm{NCR}=\mathrm{B} /(\mathrm{B}+\mathrm{F})$, where $\mathrm{B}$ and $\mathrm{F}$ are the proportions of the nematode fauna allocated to bacterivorous and fungivorous groups (Yeates et al., 2003). Three dominances were divided according to the proportions of nematode genera: "eudominant" is over 10 $\%$, "dominant" $5-10 \%$ and "subdominant" $2-5 \%$.

All the data were subjected to statistical analysis of variance (ANOVA) in the SPSS statistical package. Differences with $\mathrm{P}<0.05$ were considered significant.

\section{Results}

Significant differences in total and available $\mathrm{Pb}$ concentrations were found among sampling sites $(\mathrm{P}<0.05)$, with increase and subsequent decrease in concentrations (Fig. 1). The highest values of total and available $\mathrm{Pb}$ were found at $20 \mathrm{~m}$ and lowest value at the $320 \mathrm{~m}$ from the highway. These results indicated that total and available $\mathrm{Pb}$ concentrations decreased with increasing distance from the highway. Exceptionally, very low amount of total and available lead was present at $5 \mathrm{~m}$ from highway. Based on the Standards for Soil Environmental Quality of China (1995), the allowed value (II grade) for $\mathrm{Pb}$ is $150 \mathrm{mg} \mathrm{kg}^{-1}$ when soil $\mathrm{pH}$ value was less than 6.5 . The average concentrations of $\mathrm{Pb}$ at the sampling sites from 20,40 and $80 \mathrm{~cm}$ were above the allowed values of $\mathrm{Pb}$ (Fig. 1).
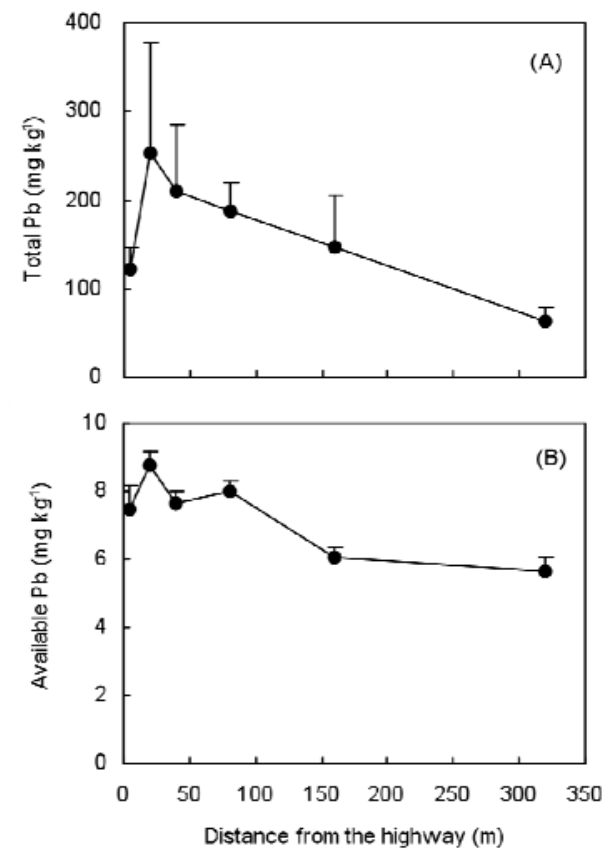

Fig. 1 Concentrations of total and available $\mathrm{Pb}($ mean $\pm \mathrm{SD})$ at different sampling sites along a pollution gradient from the Highway 
Table 1. The proportion (\%) of nematode genera and trophic groups at different sampling sites from the Highway

\begin{tabular}{|c|c|c|c|c|c|c|c|c|}
\hline Genus & Guild & $5 \mathrm{~m}$ & $20 \mathrm{~m}$ & $40 \mathrm{~m}$ & $80 \mathrm{~m}$ & $160 \mathrm{~m}$ & $320 \mathrm{~m}$ & P-value \\
\hline Acrobeles & $\mathrm{Ba}_{2}$ & 0.19 & 0.19 & 1.43 & 0.42 & 4.82 & 4.23 & NS \\
\hline Acrobeloides & $\mathrm{Ba}_{2}$ & 0 & 0.85 & 0.52 & 3.3 & 0.18 & 1.67 & NS \\
\hline Cephalobus & $\mathrm{Ba}_{2}$ & 8.74 & 6 & 5.89 & 4.9 & 10.23 & 3.47 & NS \\
\hline Chiloplacus & $\mathrm{Ba}_{2}$ & 0 & 0 & 0.91 & 1.49 & 3.29 & 2.22 & NS \\
\hline Eucephalobus & $\mathrm{Ba}_{2}$ & 7.07 & 6.98 & 2.26 & 11.19 & 6.63 & 2.03 & NS \\
\hline Mesorhabdtis & $\mathrm{Ba}_{1}$ & 0 & 4.18 & 4.11 & 0.36 & 0.83 & 0.91 & $<0.05$ \\
\hline Monhystera & $\mathrm{Ba}_{1}$ & 0 & 0.19 & 0 & 0.69 & 0.17 & 1.65 & NS \\
\hline Panagrolaimus & $\mathrm{Ba}_{1}$ & 0 & 0 & 0.32 & 0.37 & 0 & 0.36 & NS \\
\hline Prismatolaimus & $\mathrm{Ba}_{3}$ & 0.18 & 3.56 & 1.35 & 0.82 & 1.59 & 0.72 & NS \\
\hline Rhabditis & $\mathrm{Ba}_{1}$ & 0 & 0 & 0 & 0 & 1.25 & 0 & NS \\
\hline Teratocephalus & $\mathrm{Ba}_{3}$ & 0 & 0 & 0 & 0 & 0.18 & 0 & NS \\
\hline Wilsonema & $\mathrm{Ba}_{2}$ & 0.37 & 0 & 0 & 0.18 & 0 & 0.36 & NS \\
\hline Aphelenchoides & $\mathrm{Fu}_{2}$ & 8.25 & 1.87 & 2.53 & 4.14 & 5.91 & 9.41 & $<0.05$ \\
\hline Aphelenchus & $\mathrm{Fu}_{2}$ & 0.58 & 0.74 & 0.52 & 2.41 & 1.54 & 0.72 & NS \\
\hline Diptherophora & $\mathrm{Fu}_{3}$ & 0.37 & 0.34 & 0 & 0 & 0 & 0 & NS \\
\hline Dorylaimoides & $\mathrm{Fu}_{4}$ & 0.37 & 1.54 & 1.85 & 0.39 & 1.4 & 1.37 & NS \\
\hline Tylencholaimus & $\mathrm{Fu}_{4}$ & 0 & 0 & 0.35 & 0 & 0 & 0 & $<0.05$ \\
\hline Aglenchus & $\mathrm{RFF}_{2}$ & 0 & 0 & 0 & 0.18 & 0 & 0 & NS \\
\hline Boleodorus & $\mathrm{RFF}_{2}$ & 18.45 & 6.02 & 6.7 & 2.59 & 5.58 & 13.02 & $<0.05$ \\
\hline Filenchus & $\mathrm{RFF}_{2}$ & 8.65 & 3.24 & 2.66 & 6.39 & 2.56 & 2.76 & NS \\
\hline Psilenchus & $\mathrm{RFF}_{2}$ & 0.39 & 0.67 & 0 & 0.46 & 0 & 0 & NS \\
\hline Tylenchus & $\mathrm{RFF}_{2}$ & 0 & 4.31 & 2.15 & 0.18 & 2.15 & 3.51 & NS \\
\hline Epidorylaimus & $\mathrm{Om}_{4}$ & 0 & 0 & 0 & 0.2 & 0 & 0 & NS \\
\hline Eudorylaimus & $\mathrm{Om}_{4}$ & 0.37 & 0.75 & 3.79 & 5.61 & 1.52 & 2.19 & $<0.01$ \\
\hline Thornenema & $\mathrm{Om}_{4}$ & 0 & 0.75 & 0.36 & 0.22 & 0.73 & 0 & NS \\
\hline Axonchium & $\mathrm{Om}_{5}$ & 0.99 & 0.54 & 1.51 & 0.64 & 0 & 3.32 & $<0.05$ \\
\hline Dorylaimellus & $\mathrm{Om}_{5}$ & 0 & 1.14 & 0 & 0.44 & 0.59 & 0.92 & NS \\
\hline Aporcelaimellus & $\mathrm{Ca}_{5}$ & 0 & 0.33 & 0.74 & 0.22 & 1.76 & 0 & NS \\
\hline Discolaimus & $\mathrm{Ca}_{5}$ & 0 & 0 & 0 & 0 & 0.18 & 0 & NS \\
\hline Iotonchus & $\mathrm{Ca}_{4}$ & 0 & 0 & 0 & 0 & 0.18 & 0 & NS \\
\hline Mylonchulus & $\mathrm{Ca}_{4}$ & 0.97 & 0.37 & 0 & 0 & 0 & 0 & $<0.01$ \\
\hline Criconemoides & $\mathrm{H}_{3}$ & 0 & 0.38 & 0 & 0 & 0 & 0.18 & $\mathrm{NS}$ \\
\hline Helicotylenchus & $\mathrm{H}_{3}$ & 37.19 & 44.82 & 45.9 & 39.49 & 36.42 & 29.29 & NS \\
\hline Heterodera & $\mathrm{H}_{3}$ & 0 & 6.12 & 0 & 0 & 1.54 & 3.28 & $<0.01$ \\
\hline Hirschmaniella & $\mathrm{H}_{3}$ & 0 & 2.4 & 1.25 & 7.82 & 4.06 & 0.75 & $<0.01$ \\
\hline Pratylenchus & $\mathrm{H}_{3}$ & 11.51 & 6.38 & 3.24 & 7.54 & 0.92 & 9.79 & NS \\
\hline Trophurus & $\mathrm{H}_{3}$ & 2.49 & 0 & 3.16 & 1.77 & 11.54 & 0.18 & $<0.01$ \\
\hline
\end{tabular}

Thirty seven genera of nematodes from eight orders and twenty-four families were identified in our investigation (Table 1), and Helicotylenchus was eudominant genus at all the sampling sites with highest dominance (46\%) at 40 m. Pratylenchus was eudominant only at $5 \mathrm{~m}$ while Boleodorus was eudominant at $5 \mathrm{~m}$ and $320 \mathrm{~m}$. Eucephalobus and Trophurus were eudominant at $80 \mathrm{~m}$ and $160 \mathrm{~m}$, respectively. Cephalobus was present at all sites, with eudominance at the distance of $160 \mathrm{~m}$ from the highway. Aphelenchoides was dominant at $5 \mathrm{~m}, 160 \mathrm{~m}$ and $320 \mathrm{~m}$, respectively. The dominance of Aphenlenchoides and Boleodorus were all higher at $5 \mathrm{~m}$ and $320 \mathrm{~m}$ than at other sites. Mesorhabditis, Aphelenchoides, Tylencholaimus, Boleodorus, Axonchium $(\mathrm{P}<0.05)$ and Eudorylaimus,
Mylonchulus, Heterodera, Hirschmaniella, Trophurus $(\mathrm{P}<$ $0.01)$ were significantly different at different sampling distances.

The number of total nematodes increased at $40 \mathrm{~m}$ and subsequently decreased to $320 \mathrm{~m}$. The highest abundance of nematodes was at $40 \mathrm{~m}$ while lowest at $5 \mathrm{~m}$. Significant differences in the number of total nematodes $(\mathrm{P}<0.05)$ were found among sampling sites (Table 2). Except fungal feeders, which were highest at $320 \mathrm{~m}$, the number of bacterial feeders, root-fungal feeders, herbivores and omnivores-predators also showed the same trend as total nematodes. Bacterial feeders $(\mathrm{P}<0.01)$ were significantly different with distance.

Significant differences in the ecological indices including 
Table 2. Abundance (individuals per $100 \mathrm{~g}$ dry soil) of soil nematodes and ecological indices at different sampling sites from the Highway

\begin{tabular}{|c|c|c|c|c|c|c|c|}
\hline & $5 \mathrm{~m}$ & $20 \mathrm{~m}$ & $40 \mathrm{~m}$ & $80 \mathrm{~m}$ & $160 \mathrm{~m}$ & $320 \mathrm{~m}$ & P-value \\
\hline \multicolumn{8}{|c|}{ Abundance } \\
\hline TNEM & $274.0 \pm 97.0$ & $399 \pm 123.7$ & $543.8 \pm 123.2$ & $421.0 \pm 166.4$ & $307.6 \pm 94.3$ & $318.8 \pm 45.0$ & $<0.05$ \\
\hline $\mathrm{Ba}$ & $42.7 \pm 35.1$ & $81.7 \pm 45.6$ & $81.3 \pm 45.0$ & $71.8 \pm 15.8$ & $79.1 \pm 33.2$ & $52.0 \pm 14.3$ & $<0.01$ \\
\hline $\mathrm{Fu}$ & $26.6 \pm 19.8$ & $19.5 \pm 15.9$ & $28.3 \pm 23.9$ & $24.1 \pm 8.4$ & $23.2 \pm 17.3$ & $35.7 \pm 18.5$ & NS \\
\hline RFF & $58.0 \pm 14.7$ & $48.3 \pm 10.7$ & $92.2 \pm 40.0$ & $39.4 \pm 9.2$ & $29.0 \pm 5.7$ & $52.1 \pm 13.3$ & NS \\
\hline $\mathrm{H}^{\prime}$ & $139.0 \pm 20.2$ & $231.7 \pm 29.7$ & $309.6 \pm 45.2$ & $258.4 \pm 73.9$ & $161.0 \pm 30.2$ & $159.2 \pm 34.2$ & NS \\
\hline $\mathrm{Om}+\mathrm{Ca}$ & $7.6 \pm 3.3$ & $18.0 \pm 7.0$ & $32.5 \pm 8.5$ & $27.4 \pm 10.9$ & $15.2 \pm 5.4$ & $19.9 \pm 3.8$ & NS \\
\hline \multicolumn{8}{|c|}{ Ecological index } \\
\hline$\lambda$ & $0.23 \pm 0.05$ & $0.25 \pm 0.07$ & $0.36 \pm 0.20$ & $0.23 \pm 0.13$ & $0.19 \pm 0.05$ & $0.21 \pm 0.14$ & $<0.01$ \\
\hline $\mathrm{H}^{\prime}$ & $1.72 \pm 0.23$ & $1.86 \pm 0.27$ & $1.65 \pm 0.64$ & $1.95 \pm 0.39$ & $2.05 \pm 0.26$ & $2.06 \pm 0.43$ & NS \\
\hline SR & $1.39 \pm 0.40$ & $1.97 \pm 0.40$ & $1.98 \pm 0.65$ & $2.08 \pm 0.39$ & $2.22 \pm 0.72$ & $2.47 \pm 0.54$ & NS \\
\hline $\mathrm{J}^{\prime}$ & $0.80 \pm 0.03$ & $0.73 \pm 0.08$ & $0.63 \pm 0.17$ & $0.75 \pm 0.13$ & $0.80 \pm 0.09$ & $0.75 \pm 0.13$ & $<0.01$ \\
\hline$\Sigma \mathrm{MI}$ & $4.25 \pm 0.50$ & $4.93 \pm 0.65$ & $5.24 \pm 0.46$ & $4.88 \pm 0.24$ & $5.20 \pm 0.25$ & $4.69 \pm 0.39$ & NS \\
\hline MI2-5 & $2.24 \pm 0.07$ & $2.47 \pm 0.17$ & $2.74 \pm 0.22$ & $2.37 \pm 0.11$ & $2.46 \pm 0.13$ & $2.33 \pm 0.16$ & NS \\
\hline NCR & $0.59 \pm 0.17$ & $0.81 \pm 0.06$ & $0.75 \pm 0.17$ & $0.75 \pm 0.06$ & $0.79 \pm 0.14$ & $0.60 \pm 0.15$ & $<0.01$ \\
\hline
\end{tabular}

dominance $(\boldsymbol{\lambda})$, evenness $\left(\mathrm{J}^{\prime}\right)$, MI2-5 and nematode channel ratio $(\mathrm{NCR})(\mathrm{P}<0.01)$ were found at sampling sites. The lowest values of MI2-5, NCR and $\Sigma$ MI were found at $5 \mathrm{~m}$ from the highway. The values of $\lambda$ ranged from 0.19 to 0.36 , with high and low values at distance of $40 \mathrm{~m}$ and 160 $\mathrm{m}$ from the highway (Table 2). $\mathrm{H}^{\prime}$ was highest at $320 \mathrm{~m}$, while MI2-5 and NCR followed the same trend as the number of total nematodes. The obtained values of NCR ranged from 0.59 to 0.81 with highest value at $20 \mathrm{~m}$ and lowest at $5 \mathrm{~m}$.

The number of total nematodes positively correlated with total and available $\mathrm{Pb}$, while bacterial feeders correlated with total $\mathrm{Pb}(\mathrm{P}<0.05)$. SR and $\mathrm{J}$ negatively correlated with total nitrogen and total $\mathrm{Pb}(\mathrm{P}<0.05)$, while $\Sigma \mathrm{MI}$ negatively correlated to TOC, Total N, C/N $(\mathrm{P}<0.01)$ and NCR with $\mathrm{pH}(\mathrm{P}<0.01)$ (Table 3$)$. concentrations were found on east side at site $40 \mathrm{~m}$ and the lowest at $360 \mathrm{~m}$ in our study. These results were in line with those of Wang et al. (2006) in Shenyang, who found that east sides of the highways are more contaminated than west sides and Nabulo et al. (2006) in Uganda, who reported that generally highest concentrations of $\mathrm{Pb}$ were found at $30-40 \mathrm{~m}$ from highway. Increase in soil $\mathrm{Pb}$ concentration at $40 \mathrm{~m}$ may be reasoned that impact distance for $\mathrm{Pb}$ is $30 \mathrm{~m}$ to $40 \mathrm{~m}$ from a highway (Viard et al., 2004; Nabulo et al., 2006). Presence of low concentration of $\mathrm{Pb}$ nearest to highway $(5 \mathrm{~m})$ can be explained that wind is mainly responsible for deposition of lead from vehicular exhaust, and $\mathrm{Pb}$ particles travel certain distance in air before settling down in soil (Viard et al., 2004).

The number of total nematodes exhibited a gradual increasing trend to a distance and then decreasing with

Table 3. Correlation coefficients for soil nematodes and soil chemical properties at different sampling sites

\begin{tabular}{lcccccc}
\hline Indicator & $\mathrm{pH}$ & Total Pb & Available Pb & TOC & Total N & $\mathrm{C} / \mathrm{N}$ \\
TNEM & -0.11 & $0.48^{*}$ & $0.42^{*}$ & -0.16 & -0.03 & -0.10 \\
$\mathrm{Ba}$ & -0.38 & $0.41^{*}$ & 0.29 & -0.34 & -0.26 & -0.31 \\
$\mathrm{Fu}$ & 0.30 & -0.28 & -0.28 & 0.05 & -0.09 & 0.17 \\
$\mathrm{RFF}$ & 0.09 & -0.06 & 0.19 & 0.07 & 0.01 & 0.14 \\
$\mathrm{H}^{\prime}$ & -0.18 & 0.32 & 0.25 & -0.16 & -0.14 & -0.07 \\
$\mathrm{Om}+\mathrm{Ca}$ & -0.14 & 0.15 & 0.04 & -0.19 & -0.22 & -0.04 \\
$\lambda$ & -0.14 & 0.33 & 0.30 & 0.05 & 0.07 & 0.02 \\
$\mathrm{H}^{\prime}$ & -0.09 & -0.35 & -0.31 & -0.24 & -0.38 & 0.02 \\
$\mathrm{SR}$ & -0.19 & -0.05 & -0.24 & -0.36 & $-0.40^{*}$ & -0.13 \\
$\mathrm{~J}^{\prime}$ & 0.22 & $-0.46^{*}$ & -0.10 & 0.06 & 0.02 & 0.06 \\
$\Sigma \mathrm{MI}$ & -0.27 & 0.37 & -0.17 & $-0.60 * *$ & $-0.52 * *$ & $-0.43^{*}$ \\
$\mathrm{MI} 2-5$ & -0.27 & 0.27 & 0.02 & -0.07 & -0.05 & -0.04 \\
$\mathrm{NCR}$ & $-0.57 * *$ & 0.20 & 0.34 & -0.24 & -0.02 & -0.33 \\
\hline
\end{tabular}

Explanations: *, ** - Correlations are significant at $\mathrm{P}<0.05$ and 0.01 levels, respectively

\section{Discussion}

Aerial deposition of $\mathrm{Pb}$ emitted from the heavy and light traffic passing on the highway caused an increase in heavy metal concentrations in the investigated soils. The highest increase in distance from the highway in our investigation, well explained by positive correlation of total number of nematode with total and available $\mathrm{Pb}$, thus $\mathrm{Pb}$ had effects on the number of total nematodes.

Response of nematode abundance to heavy metals is vari- 
able, the population of nematodes may increase or decrease with heavy metal concentration (Sanchez-Moreno \& Navas, 2007). The numbers of bacterivores correlated positively with total $\mathrm{Pb}$ in soil in our study. These results indicated that $\mathrm{Pb}$ had a positive effect on bacterivorous nematodes although this does not fully agree with Sanchez-Moreno and Navas (2007), who found low populations of bacterial and fungal feeding nematodes in heavy metal polluted soils. It may be due to fact that heavy metal toxic effects may disappear due to adaption of organisms (Haimi \& Matasniemi, 2001). Herbivores were most dominant trophic group in our study. The high abundance of herbivores was at the medium $\mathrm{Pb}$ concentration which agrees well with Korthals et al. (1998) who reported that intermediate pollutant concentrations may be beneficial to plant parasites as due to increase in nutrient availability and a higher leakage of root exudates may occur which plays a role between plant parasites and heavy metal concentration. Helicotylenchus was most eudominant genus that can be explained in a crop field presence of plant roots leads to abundant resources for plant parasites and hence they build up their population. The correlation between total and available $\mathrm{Pb}$ and Aphenlenchoides was negatively significant. Higher dominance of Aphenlenchoides appeared at $5 \mathrm{~m}$ and $320 \mathrm{~m}$ with low concentrations of $\mathrm{Pb}$. However, no significant correlation between the concentration of $\mathrm{Pb}$ and Boleodorus was found and its distribution was probably better explained by the joint action of soil properties and heavy metals. Omnivorepredators were least abundant in our study and the most sensitive trophic group to heavy metal pollution, which fully agrees with Georgieva et al. (2002) and Zhang et al. (2006) who reported that the population of omnivorepredators was reduced due to increase in concentrations of heavy metals.

MI2-5 gives a much better response to disturbances than MI (Nagy et al., 2004). The values of MI2-5 in our investigation ranged from 2.46 to 3.19 , which agree well with that reported by Nagy et al. (2004) in Hungary and Zhang et al. (2006) in China. The nematode channel ratio (NCR) is known to be an important indicator of the decomposition pathway in the soil food webs (Yeates et al., 2003). The values of NCR in our study ranged from 0.59 to 0.81 with highest value at $20 \mathrm{~m}$ and lowest at $5 \mathrm{~m}$. The values of NCR indicated the bacterial decomposition pathway was relatively more dominant at $20 \mathrm{~m}$. The values of NCR correlated negatively with $\mathrm{pH}(\mathrm{P}<0.01)$ in our study. The lower NCR values may result from lower $\mathrm{pH}$ values. A higher value of NCR may reflect the abundance of mycorrhizal fungi (De Goeda et al., 1993).

It can be concluded from present study that total and available $\mathrm{Pb}$ in soil had a positive correlation with the number of total nematodes as well as with that of bacteriovores. The concentration of $\mathrm{Pb}$ also have effect on abundance of Helicotylenchus, which increases in moderate concentration of $\mathrm{Pb}$. NCR could be effectively used as indicators, as it was sensitive to concentration of $\mathrm{Pb}$. Thus nematodes can serve as useful bioindicators of heavy metal pollution to reflect the condition of soil ecosystem.

\section{Acknowledgements}

This research was supported by the National Natural Science Foundation of China (No. 30600087) and the Innovative Program of Institute of Applied Ecology, Chinese Academy of Sciences (06LYQY5001). V. V. S. Tomar and $\mathrm{X}$. K. Zhang contributed equally to this work.

\section{References}

Berkelmans, R., Ferris, H., Tenuta, M., VAN BRUGGEN, A. H. C. (2003): Effect of long term crop management on nematode trophic levels other than plant feeders disappear after 1 year of disruptive soil management. Appl. Soil Ecol., 23: 223 - 235

BONGERS, T. (1990): The maturity index: an ecological measure of environmental disturbance based on nematode species composition. Oecologia, 83: 14 - 19

Bongers, T., FERris, H. (1999): Nematode community structure as a bioindicator in environmental monitoring. Trends Ecol. Evol., 14: 224 - 228

De-Goede, R. G. M., Georgieva, B. C., Verschoor, B. C., Kamerman, J. (1993): Changes in nematode community structure in a primary succession of blown-out areas in a drift sand landscape. Fund. Appl. Nematol., 16: $501-513$

Ferris, H., Matute, M. M. (2003): Structural and functional succession in the nematode fauna of a soil food web. Appl. Soil Ecol., 23: $93-110$

Garcia, R., Millan, E. (1998): Assessment of Cd, Pb and $\mathrm{Zn}$ contamination in roadside soils and grasses from Gipuzkoa (Spain). Chemosphere, 37: 1615 - 1625

Georgieva, S. S., McGrath, S. P., Hooper, D. J., CHAMBERS, B. S. (2002): Nematode communities under stress: the long-term effects of heavy metals in soil treated with sewage sludge. Appl. Soil Ecol., 20: 27 - 42

HAimi, J., MATASNIEMI, L. (2001): Soil decomposer animal community in heavy-metal contaminated coniferous forest with and without liming. Eur. J. Soil Biol., 38: $131-$ 136

HÁNĚL, L. (2004): Response of soil nematodes inhabiting spruce forests in the Šumava Mountains to disturbance by bark beetles and clear-cutting. For. Ecol. Manag., 202: 209 $-225$

HuA, J. F., JiANG, Y., LiAnG, W. J. (2006): Response of nematodes in a Hapli-Udic Argosol to urea amended with urease and nitrification inhibitors. Pedosphere, 16: $428-$ 434

Korthals, G. W., De Goede, R. G. M., Kammenga, J. E., Bongers, T. (1996): The maturity index as an instrument for risk assessment of soil pollution. In VAN StraAlen, N.M., KRVOLUTSKY, D. A. (Eds.): Bioindicator Systems for Soil Pollution. Kluwer Academic publishers, The Netherlands, pp. 85 - 93

Korthals, G. W., Popovici, I., ILEIV, I. (1998): Effects of copper and zinc on terrestrial nematode community af- 
fected by the presence of perennial ryegrass. Appl. Soil Ecol., 10: 73 - 85

LI, Q., JiANG, Y., LIANG, W. J. (2006): Effect of heavy metals on soil nematode communities in the vicinity of a metallurgical factory. J. Environ. Sci., 18: $323-328$

LiAnG, W. J., ZhONG, S., HuA, J. F., CAO, C. Y., JiAnG, Y. (2007): Nematode faunal response to grassland degradation in Horqin Sandy Land. Pedosphere, 17: $611-618$

Mielke, H. W., Dugas, D., Mielke Jr., P. W., Smit, K. S., Smith, S. L., Gonzales, C. R. (1997): Associations between soil lead and children's blood lead in urban New Orleans and rural Lafourche Parish of Louisiana. Environ. Health Perspect., 105: 950 - 954

Nabulo, G., Oryem-Origo, H., Diamond, M. (2006): Assessment of lead, cadmium and zinc contamination of roadside soils, surface films and vegetables in Kampala city, Uganda. Environ. Res., 101: 42 - 52

NAGy, P., BAKONYI, G., BONGERS, T., KÁDÁR, I., FÁBiÁN, M., KISS, I. (2004): Effects of microelements on soil nematode assemblages seven years after contaminating an agricultural field. Sci. Total Environ., 320: 131 - 143

NEHER, D. A. (2001): Role of nematodes in soil health and their use as indicators. J. Nematol., 33: $161-168$

OKADA, H., HARAdA, H., KAdOTA, I. (2005): Fungalfeeding habits of six nematode isolates in the genus Filenchus. Soil Biol. Biochem., 37: 1113 - 1120

Piron-Frenet, M., Bureau, F., Pineau, R. (1994): Lead accumulation in surface roadside soil: its relationships to traffic density and meteorological parameters. Sci. Total Environ., 144: 297 - 304

QIN, Y., LOU, Y. L., JiANG, Y., LIANG, W. J. (2009): Pollution characteristic and assessment of heavy metals in farmland soil beside Shenyang-Harbin superhighway. $J$. Agro-Environ. Sci., 28: 663 - 667 (in Chinese)

RENČO, M. (2004): Communities of nematodes in cereal fields following sugar beet. Helminthologia, 41: $109-122$

SANCHEZ-MORENO, S., NAVAS, A. (2007): Nematode diversity and food web condition in heavy metal polluted soils in a river basin in Southern Spain. Eur. J. Soil Biol., 43: $166-179$

Sezgin, N., Ozcan, H. K., Demir, G., Nemlioglu, S., BAYAT, C. (2003): Determination of heavy metal concen- trations in street dusts in Istanbul, E-5 highway. Environ. Int., 29: 979 - 985

Shukurov, N., Pen-Mouratov, S., Steinberger, Y. (2005): The impact of Almalyk industrial complex on soil chemical and biological properties. Environ. Pollut., 136: $331-340$

TOMAR, V. V. S., Baniyamuddin, M. D., Ahmad, W. (2006): Community structure of soil inhabiting nematodes in a Mango Orchard at Aligarh, India. Int. J. Nematol., 16: $89-101$

Turer, D. G., MAYNARD, B. J. (2003): Heavy metal contamination in highway soils: comparison of Corpus Christi, Texas and Cincinnati, Ohio shows organic matter is key to mobility. Clean Technol. Environ. Policy, 4: 235 - 245

Viard, B., Pihan, F., Promeyrat, S., Pihan, J.-C. (2004): Integrated assessment of heavy metal (Pb, Zn, Cd) highway pollution: bioaccumulation in soil, Graminaceae and land snails. Chemosphere, 55: 1349 - 1359

WANG, J., REN, H., ZHANG, X. (2006): Distributions patterns of lead in urban soil and dust in Shenyang city, NorthEast China. Environ. Geochem. Health, 28: 53 - 59

YEATES, G. W., BONGERS, T. (1999): Nematode diversity in agro-ecosystems. Agric. Ecosyst. Environ., 74: 113 - 135

Yeates, G. W., Bongers, T., De Goede, R. G. M., Freckman, D. W., Georgieva, S. S. (1993): Feeding habits in soil nematode families and genera - an outline for soil ecologists. J. Nematol., 25: 315 - 331

Yeates, G. W., Percival, H. J., Parshotam, A. (2003): Soil nematode responses to year-to-year variation of low levels of heavy metals. Aust. J. Soil Res., 41: 613-625 Zhang, H., MA, D., XIE, Q., CHEN, X. (1999): An approach to studying heavy metal pollution caused by modern city development in Nanjing, China. Environ. Geol., 38: $223-228$

ZHANG, W. D., WANG, X. F., LI, Q., JiANG, Y., LIANG, W. J. (2007): Soil nematode responses to heavy mental stress. Helminthologia, 44: 87 - 91

ZHANG, X. K., LI, Q., WANG, S. B., JiANG, Y., LiANG, W. (2006): Effect of zinc addition to soil on nematode community structure. Bull. Environ. Contam. Toxicol., 76: 589 $-594$

ACCEPTED August 25, 2009 